\begin{tabular}{|c} 
Ambiente \& Água - An Interdisciplinary Journal of Applied Science \\
ISSN 1980-993X - doi:10.4136/1980-993X \\
www.ambi-agua.net \\
E-mail: ambi.agua@gmail.com
\end{tabular}

\title{
Evaluation of the use of fertilizer obtained from pharmaceutical effluent
}

\author{
ARTICLES doi:10.4136/ambi-agua.2262
}

Received: 28 Mar. 2018; Accepted: 26 May 2019

\author{
Carina Aline Prado ${ }^{1}$; Mariana Paiva Batagini Giron ${ }^{1}$; \\ Fernanda Gonçalves Mendes $^{2}{ }^{(D}$; Marco Aurélio Kondracki de Alcântara ${ }^{2 *}$;D; \\ Hélcio José Izário Filho1 ${ }^{1}$ \\ ${ }^{\mathbf{1}}$ Escola de Engenharia de Lorena (EEL-USP), Lorena, SP, Brasil \\ Departamento de Engenharia de Química (DEQUI).E-mail: carinaprado@usp.br, \\ marianabatagini@usp.br, helcio@dequi.eel.usp.br \\ ${ }^{2}$ Escola de Engenharia de Lorena (EEL-USP), Lorena, SP, Brasil \\ Departamento de Ciências Básicas e Ambientais (LOB). \\ E-mail: fernanda@alunos.eel.usp.br,marko@usp.br \\ *Corresponding author
}

\begin{abstract}
Sustainability encompasses several aspects, one of which is the reuse of nutrient-rich effluent. In recent years, improper disposal of pharmaceuticals and pharmaceutical effluent, which contain recalcitrant compounds, has caused great environmental damage. An alternative disposal strategy that has been studied for several residues is their reuse for agricultural purposes. This work evaluated the potential of using pharmaceutical effluent for fertilizing Schinus molle, a native Brazilian species locally known as "aroeira-salsa." Effluent was pretreated by chemical precipitation, and the solid phase was tested as fertilizer. Seedlings were grown in soil or compost. The soil used was classified as Red-Yellow Acrisol with medium loamy texture and high Al content, which is typically found in the Vale do Paraíba region, São Paulo, Brazil. Two agricultural composts were used as substrate, both from the Taboão Ecological Park located in Vale do Paraíba. Fertilizer application improved the physicochemical characteristics of all growing media, increasing $\mathrm{C}, \mathrm{N}, \mathrm{P}, \mathrm{K}, \mathrm{Mg}$, and $\mathrm{Ca}$ contents, base saturation, and $\mathrm{pH}$, while decreasing $\mathrm{Al}$ content and density. Fertilization improved nutrient absorption and plant growth.
\end{abstract}

Keywords: fertilizer, pharmaceutical effluent, sustainability.

\section{Avaliação do uso de fertilizante obtido a partir de efluente de indústria farmacêutica}

\section{RESUMO}

A sustentabilidade envolve um número grande de aspectos. Entre eles, o de aproveitamento de nutrientes presentes em efluentes tratados com diferentes tipos de processos. Nos últimos anos, têm sido detectados danos ambientais decorrentes do despejo de fármacos e de efluentes da indústria farmacêutica, em função da difícil recalcitrância de alguns componentes das formulações. Um destino que tem sido estudado para diversos tipos de rejeitos é a aplicação no solo com finalidade agrícola. Visando o aproveitamento de efluentes da indústria farmacêutica 
(e consequente redução de um passivo ambiental), foi desenvolvido e utilizado um fertilizante obtido a partir da precipitação química (pré-tratamento) de um efluente. O fertilizante obtido foi testado para espécie Schinus molle, popularmente denominada de aroeira-salsa no Brasil. As plantas se desenvolveram tendo como substrato solo ou compostos orgânicos. O solo utilizado foi um Argissolo Vermelho-Amarelo textura média, característico da região do vale do Paraíba, Estado de São Paulo, Brasil, com alto teor de alumínio. Foram utilizados dois compostos orgânicos, originados de resíduos agrícolas, ambos provenientes do Parque Ecológico do Taboão, localizado no Vale do Paraíba. A aplicação do fertilizante em todos os substratos melhorou as suas características em relação aos teores de $\mathrm{C}, \mathrm{N}, \mathrm{P}, \mathrm{K}, \mathrm{Mg}, \mathrm{Ca}$, saturação por bases, $\mathrm{pH}, \mathrm{Al}$ e densidade. Também a absorção de nutrientes e o crescimento das plantas foi beneficiado com a aplicação do fertilizante.

Palavras-chave: efluente de indústria farmacêutica, fertilizante, sustentabilidade.

\section{INTRODUCTION}

Environmental sustainability involves multiple aspects. One is the reuse of waste materials rich in nutrients and organic matter. Adequate disposal of nutrient-rich effluent prevents chemical and microbiological contamination and reduces environmental impact. Incorporation of wastewater into the soil or other agricultural substrates for fertilization purposes is an interesting alternative from a sustainability and environmental conservation perspective. Wastewater treatment can produce profitable materials, thereby favoring sustainable economic activities and fostering the creation of economically viable environmental programs and new waste disposal sites for industries. Such projects reduce environmental pollution and impacts and raise public awareness of environmental issues (Gouveia, 2012).

Effluents must meet several requirements prior to discharge into water bodies, according to CETESB Article 18 (CETESB, 2002) and CONAMA Resolution No. 430 (CONAMA, 2005). Thus, adequate treatment of wastewaters is of extreme importance for environmental preservation and law compliance. In some cases, depending on the recalcitrance of its components, wastewater may require a post-treatment step to meet discharge standards, such as biological treatment.

Pharmaceutical industries generate large amounts of waste with high organic content. Residues resulting from the production of antibiotics are an example of materials that contain recalcitrant components of high molecular weight. At high concentrations, these compounds are difficult to treat by conventional methods. For this reason, pharmaceutical wastewater is frequently dried and incinerated rather than treated, especially when the cost/benefit ratio is high. It thus becomes necessary to resort to emerging technologies or to a combination of two or more processes (for instance, chemical precipitation and advanced oxidation process) to treat pharmaceutical wastewater.

Discharge of pharmaceuticals and untreated pharmaceutical wastewater into domestic sewer lines, surface water, and groundwater has caused great environmental damage (Melo et $a l ., 2009)$. These wastes contain compounds of several therapeutic classes, such as hormones, analgesics, and antibiotics.

The agricultural industry generates large amounts of solid waste, including straw, crop residues, and animal wastes. Hundreds of metric tons of organic waste are generated annually in Brazil, which can be either a serious source of pollution if untreated or a valuable agricultural input to replace industrialized fertilizers.

Composting, one of the most environmentally friendly alternatives for recycling organic waste, is a controlled process of organic waste degradation under aerobic conditions. Compost can supply essential nutrients, especially carbon, for plant growth and also improve some physical characteristics of the soil, including soil density, a property that varies according to 
soil compaction. The decrease in soil density promoted by the addition of organic matter facilitates root penetration and increases total porosity, macroporosity, water permeability, and water infiltration (FAO, 2005).

An environmentally sustainable agricultural system requires that soil nutrient and organic matter reserves be preserved. Carbon and nitrogen are important for plant growth. Stable soil organic matter is a source of essential nutrients for plant development (LAL, 2008; Misiewicz et al., 2017).

Achieving sustainability is the goal of various agricultural production systems (Karlen and Rice, 2017). Agroforestry, for instance, has seedling cultivation and tree planting as some of its core practices. Different substrates are used to grow seedlings until they can be planted. Substrate is a medium for growing plants $e x$ situ. Mineral soil was the first substrate used for ex situ cultivation. Currently, most substrates consist of a combination of two or more components, which can be chosen from a large variety of materials.

Many studies showed that soil amendment with organic waste positively influences soil characteristics and plant development. Gomes et al. (2004) conducted a study on the cultivation of Anadenanthera colubrina in Red-Yellow Acrisol and reported that nutrient addition promoted an increase in base saturation, which in turn improved plant growth and resulted in increased dry weight. Cultivated species require the addition of adequate levels of nutrients to the culture medium. Soil organic matter is the primary source of nutrients in cultivated soils and serves as a temporary nutrient reserve. Its importance in maintaining and improving physical characteristics of the soil, such as water and air infiltration, water retention, and soil aggregation, and in controlling the fate of pesticides is well known (Srinivasan et al., 2012).

Maintaining and increasing soil organic matter levels in the highly weathered soils of tropical regions is a great challenge. In tropical agricultural areas, organic residues and fertilizers are frequently applied to the soil to enhance microbial activity and mineralization rates (Guimarães et al., 2014).

Studies analyzed the effects of wastewater or effluent irrigation. Depending on the characteristics of the material, either positive or negative effects may follow. A comprehensive review of this topic was published by Kaur and Sharma (2013). The study provided a list of effluents that can be used for fertilization purposes but underscored that some may negatively impact physical and chemical soil characteristics. Kalyva (2017) presented a review of the disposal of pharmaceuticals in the environment, discussing their fate, transport, aquatic and terrestrial pollution potential, and risks to populations. Probably because of the well-known negative impacts of pharmaceuticals on the environment, few works focus on investigating the beneficial effect of pharmaceutical wastewater irrigation.

This study aimed to evaluate the potential of using a fertilizer obtained from pharmaceutical wastewater to grow Schinus molle in different substrates. The effects of fertilizer addition on chemical and physical characteristics of substrates, plant growth, and nutrient absorption were evaluated.

\section{MATERIALS AND METHODS}

Pharmaceutical effluent, specifically, effluent from syrup production, was used to obtain the fertilizer. In addition to pharmaceuticals, the effluent had a high content of sucrose, N, K, $\mathrm{Mg}, \mathrm{Na}$, and $\mathrm{P}$ (in the form of phosphate). The presence of these elements and the high $\mathrm{C}$ content (present in sucrose) makes this material a potential source of plant nutrients.

As the effluent had a high organic load, treatment by oxidation processes would not be feasible. Organic matter was therefore chemically precipitated via an innovative process. Sucrose was the major component of the precipitate. Detailed information about the precipitation reaction will not be presented in this paper because the process is being patented. After precipitation, pretreated wastewater was submitted to vacuum filtration to separate the 
solid phase from the liquid phase. A calcium hydroxide $\left(\mathrm{Ca}(\mathrm{OH})_{2}\right)$ solution was added to the solid phase at $1: 3(\mathrm{w} / \mathrm{w})$. The mixture was oven-dried at $105^{\circ} \mathrm{C}$ to avoid chemical and microbiological degradation during storage. The dried material was ground and sieved through $2 \mathrm{~mm}$ sieves, affording the fertilizer used in plant experiments. Grinding and sieving provides powders with standardized particle sizes and promotes particle homogenization, which improves soil reactivity. The liquid phase obtained after filtration was not used in this work. It will be treated by an oxidation process to meet the legal requirements for wastewater discharge. Figure 1 shows a flow diagram of the process used to obtain the fertilizer. The process can be used in an industrial setting.

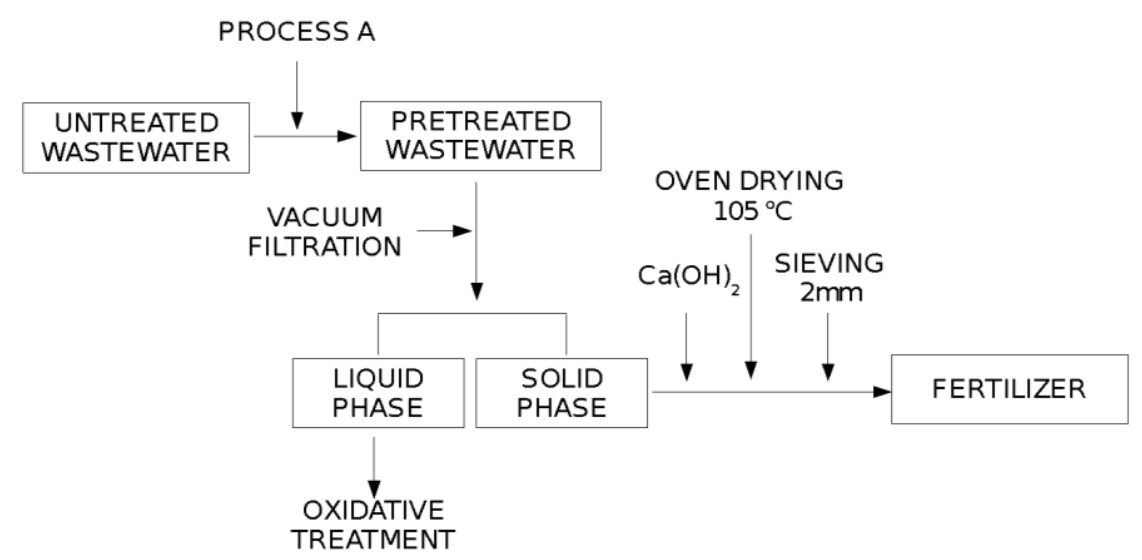

Figure 1. Scheme for obtaining fertilizer from untreated pharmaceutical effluent. Process A is used in an innovative process (patent pending).

S. molle (popularly known in Brazil as "aroeira-salsa") was used for the experiments. Samples were collected from the Taboão Ecological Park, Lorena, São Paulo, Brazil $\left(22^{\circ} 47^{\prime} 26^{\prime \prime} \mathrm{S} 45^{\circ} 66^{\prime} 11^{\prime \prime} \mathrm{W}\right)$. The species grows rapidly and has a high ornamental value in the Zona da Mata mesoregion of Minas Gerais (Mafia et al., 2004). It is naturally found in semideciduous seasonal forests in Paraná and in other ecosystems. The species is also available in nurseries throughout Vale do Paraíba.

We evaluated the effects of two factors, substrate and fertilization, on plant growth and nutrition. Three types of substrates were evaluated with and without the addition of fertilizer, in triplicate, totaling 18 experiments.

Soil or composts (obtained by aerobic composting) were used as substrates. Red-Yellow Acrisol with medium loamy texture (EMBRAPA, 2006) was collected at a depth of 0-20 cm. The soil is typically found in the study region. Composts were produced in the Taboão Ecological Park, located in Vale do Paraíba. Compost 1 was obtained from a nursery that grows seedlings of trees native to the Atlantic Forest. It was composed of several organic residues generated in the Park, such as pruning and mowing residues, cattle manure, and wastewater from washing tubes and livestock pens, as well as sand and worm humus. Compost 2 was composed of grasses and leaves and was obtained from a nursery in the Taboão Ecological Park. Fertilizer was used at $40 \mathrm{~g} \mathrm{~kg}^{-1}$ soil to provide the necessary amount of nitrogen for nursery growth (Van Raij et al., 1997).

Substrates and fertilizer were sieved through a $2 \mathrm{~mm}$ sieve. One-month-old seedlings were planted in $0.25 \mathrm{~L}$ black plastic bags and kept at room temperature for 90 days. Plants received the same amount of water throughout the growing period. All nursery practices (establishment of the nursery site, seedling formation, and seedling handling) were in accordance with the guidelines of the Brazilian Agricultural Research Corporation (EMBRAPA, 2016).

After the growing period, substrates and aerial parts of the plants were characterized 
chemically and physically following the methods of EMBRAPA (2009; 2011). Aerial parts were oven dried at $65^{\circ} \mathrm{C}$ and the dry weight was measured. Plant height was also determined. The density of growing media was determined or quantified following the methods of EMBRAPA (2009).

Available $\mathrm{Ca}, \mathrm{Mg}, \mathrm{K}, \mathrm{Na}$, and $\mathrm{P}$ were extracted with Mehlich 3 extraction, and exchangeable $\mathrm{Al}$ was extracted using a $1 \mathrm{~mol} \mathrm{~L}^{-1} \mathrm{KCl}$ solution. The elements were quantified by inductively coupled plasma optical emission spectrometry (ICP-OES). Chemical oxygen demand (COD) was determined to estimate the amount of C. Organic matter was oxidized by potassium dichromate in acidic medium at high temperature in the presence of a catalyst. Subsequently, absorbance was measured at $620 \mathrm{~nm}$. N content was determined by digesting the sample in acidic medium, followed by distillation using borate/sodium hydroxide buffer to adjust the $\mathrm{pH}$ to 9.5 . The concentration of ammonia $\mathrm{N}$ was quantified spectrophotometrically at $420 \mathrm{~nm}$. Analyses were performed when the plants were collected and at the end of the evaluation period (90 days).

\section{RESULTS AND DISCUSSION}

Table 1 shows the physicochemical characteristics of the fertilizer. Its neutral $\mathrm{pH}$ (7.0), high content of organic carbon and base cations $(\mathrm{Ca}, \mathrm{Mg}$, and $\mathrm{K})$, and undetectable $\mathrm{Al}$ content are interesting features for agricultural application.

Table 1. Physicochemical characteristics of the fertilizer.

\begin{tabular}{lcc}
\hline Parameter & Unit & Value \\
\hline $\mathrm{pH}$ & - & $7.0 \pm 0.0$ \\
$\mathrm{Al}$ & $\mathrm{mg} \mathrm{g}^{-1}$ & $<0.001$ \\
$\mathrm{Ca}$ & $\mathrm{mg} \mathrm{g}^{-1}$ & $405.85 \pm 0.01$ \\
$\mathrm{Mg}$ & $\mathrm{mg} \mathrm{g}^{-1}$ & $36.21 \pm 0.01$ \\
$\mathrm{P}$ & $\mathrm{mg} \mathrm{g}^{-1}$ & $35.96 \pm 0.07$ \\
$\mathrm{~K}$ & $\mathrm{mg} \mathrm{g}^{-1}$ & $111.23 \pm 0.01$ \\
$\mathrm{Na}$ & $\mathrm{mg} \mathrm{g}^{-1}$ & $16.10 \pm 0.01$ \\
$\mathrm{~N}$ & $\mathrm{mg} \mathrm{g}^{-1}$ & $52.35 \pm 0.11$ \\
$\mathrm{OC}$ & $\mathrm{mg} \mathrm{dm}^{-3}$ & $3100 \pm 0.01$ \\
Density & $\mathrm{kg} \mathrm{dm}^{-3}$ & $1.017 \pm 0.010$ \\
\hline OC, organic carbon. Values represent the \\
mean \pm standard deviation. Three replicates.
\end{tabular}
Table 2.

The physicochemical characterization of fertilized and unfertilized substrates is shown in

Several beneficial effects of the addition of fertilizer to growing media were observed, such as an increase in $\mathrm{pH}$, cation content, and base saturation and a decrease in exchangeable Al. A three-fold increase in organic carbon content was obtained with the addition of fertilizer as well as an increase in plant-available $\mathrm{P}$ and N. Regarding the substrates' physical characteristics, there was a small decrease in soil density, which is also a favorable effect. An increase in $\mathrm{Na}$ content was observed in fertilized soil as compared with unfertilized soil; however, the same was not observed for composts 1 and 2. This effect in soil nutrient content may be due to the chemical components used in the process to obtain the fertilizer. 
Table 2. Physicochemical characteristics of fertilized and unfertilized substrates.

\begin{tabular}{|c|c|c|c|c|c|c|c|}
\hline \multirow{2}{*}{ Parameter } & \multirow{2}{*}{ Unit } & \multirow{2}{*}{$\frac{\text { Soil }}{\text { Unfertilized }}$} & \multirow{2}{*}{$\begin{array}{l}\text { Compost } 1 \\
\text { Fertilized }\end{array}$} & \multicolumn{4}{|c|}{ Compost 2} \\
\hline & & & & Unfertilized & Fertilized & Unfertilized & Fertilized \\
\hline $\mathrm{pH}$ & - & $5.7 \pm 0.1$ & $7.0 \pm 0.0$ & $5.6 \pm 0.0$ & $6.7 \pm 0.0$ & $5.4 \pm 0.0$ & $6.5 \pm 0.0$ \\
\hline $\mathrm{Al}$ & $\mathrm{mg} \mathrm{g}^{-1}$ & $48.00 \pm 0.00$ & $46.50 \pm 0.01$ & $37.41 \pm 0.02$ & $35.21 \pm 0.05$ & $38.41 \pm 0.01$ & $31.74 \pm 0.05$ \\
\hline $\mathrm{Ca}$ & $\mathrm{mg} \mathrm{g}^{-1}$ & $1.04 \pm 0.00$ & $84.12 \pm 0.01$ & $4.02 \pm 0.01$ & $66.12 \pm 0.02$ & $10.12 \pm 0.01$ & $424.2 \pm 0.0$ \\
\hline $\mathrm{Mg}$ & $\mathrm{mg} \mathrm{g}^{-1}$ & $<0.001$ & $36.20 \pm 0.00$ & $0.01 \pm 0.02$ & $3.65 \pm 0.01$ & $0.08 \pm 0.00$ & $40.1 \pm 0.1$ \\
\hline $\mathrm{P}$ & $\mathrm{mg} \mathrm{g}^{-1}$ & $23.20 \pm 0.01$ & $28.73 \pm 0.01$ & $6.08 \pm 0.04$ & $29.73 \pm 0.01$ & $6.19 \pm 0.01$ & $36.9 \pm 0.1$ \\
\hline $\mathrm{K}$ & $\mathrm{mg} \mathrm{g}^{-1}$ & $87.80 \pm 0.01$ & $96.05 \pm 0.01$ & $7.20 \pm 0.00$ & $97.20 \pm 0.03$ & $9.70 \pm 0.02$ & $88.01 \pm 0.08$ \\
\hline V\% & - & $25 \pm 0$ & $45 \pm 0$ & $22 \pm 0$ & $56 \pm 0$ & $20 \pm 0.0$ & $50 \pm 0$ \\
\hline $\mathrm{Na}$ & $\mathrm{mg} \mathrm{g}^{-1}$ & $<0.001$ & $0.013 \pm 0.004$ & $<0.001$ & $<0.001$ & $<0.001$ & $1.301 \pm 0.003$ \\
\hline $\mathrm{N}$ & $\mathrm{mg} \mathrm{g}^{-1}$ & $26.7 \pm 0.0$ & $61.4 \pm 0.0$ & $0.2 \pm 0.0$ & $31.4 \pm 0.0$ & $12 \pm 0.0$ & $61.4 \pm 0.0$ \\
\hline OC & $\mathrm{mg} \mathrm{mg}^{-3}$ & $36.20 \pm 0.00$ & $106.40 \pm 0.01$ & $45.20 \pm 0.01$ & $106.4 \pm 0.0$ & $32.00 \pm 0.01$ & $105.4 \pm 0.0$ \\
\hline $\mathrm{D}_{\mathrm{s}}$ & $\mathrm{kg} \mathrm{dm}^{-3}$ & $1.217 \pm 0.020$ & $1.204 \pm 0.060$ & $1.227 \pm 0.001$ & $1.204 \pm 0.010$ & $1.257 \pm 0.002$ & $1.214 \pm 0.003$ \\
\hline
\end{tabular}

There is a lack of research on the use of pharmaceutical wastewater as soil fertilizer, which hinders comparison of the results obtained in the present work. However, various studies have assessed the impacts of different wastewaters on soil. In a long-term field experiment, Al Omron et al. (2012) observed an increase in soil organic matter (from 17\% to 30\%) in sewage-irrigated soils as compared with soils irrigated with well water. The increase of 13 percentage points is considerably lower than that observed in the present study. Sewage irrigation reduced soil bulk density, as observed in the present study with the addition of wastewater-derived fertilizer.

Positive and negative reported effects of wastewater on soil $\mathrm{pH}$ have been reported in the literature. Al Omron et al. (2012) observed that soil $\mathrm{pH}$ decreased with sewage irrigation. Contrarily, other authors (El-Hady, 2007; Osaigbovo and Orhue, 2006; Rusan et al., 2007) reported an increase in soil $\mathrm{pH}$ with wastewater irrigation, as was the case in the present study. 
Domestic sewage sludge might increase soil fertility. Yadav et al. (2002) reported a build up of total $\mathrm{N}\left(2908 \mathrm{~kg} \mathrm{ha}^{-1}\right)$, available $\mathrm{P}\left(58 \mathrm{~kg} \mathrm{ha}^{-1}\right)$, and available $\mathrm{K}\left(305 \mathrm{~kg} \mathrm{ha}^{-1}\right)$ in the soil. In the present study, soil $\mathrm{N}$ increased from 31.2 to $49.4 \mathrm{mg} \mathrm{kg}^{-1}$ after fertilization. Considering that the lowest soil bulk density was $2.4 \mathrm{~kg} \mathrm{dm}^{-3}$, we estimate that the increase in $\mathrm{N}$ content obtained in our study (from 75 to $118 \mathrm{~kg} \mathrm{ha}^{-1}$, approximately) was substantially higher than that of Yadav et al. (2002). P content increased from 13 to $73 \mathrm{~kg} \mathrm{ha}^{-1}$, reaching values higher than that of the mentioned study, whereas $\mathrm{K}$ content increased from 9 to $216 \mathrm{~kg} \mathrm{ha}^{-1}$ because the fertilizer was relatively poor in this nutrient.

We emphasize that this type of comparison should be performed with extreme caution. The wastewaters evaluated in the above-mentioned studies are different from the wastewater used in of our study, as are the rates and periods of application, soil type, and plants. The comparisons indicate that the changes in soil parameters observed in this work are of the same order of magnitude as those reported in the literature.

Sodification ( $\mathrm{Na}$ accumulation) might occur with as a result of frequent wastewater irrigation (FAO, 2007). In this case, Na might displace other cations, such as $\mathrm{Ca}$ and $\mathrm{Mg}$. High sodium levels might affect soil structure by reducing soil permeability (Sumner, 1993). In the present study, soil $\mathrm{Na}$ content did not increase substantially with fertilizer application. However, seedlings were cultivated for a short period. Long-term field application is necessary to evaluate better the effects of $\mathrm{Na}$ on soil and plant characteristics.

Figure 2 shows photographs of plants at 30,60, and 90 days of cultivation in fertilized and unfertilized Acrisol. Photographs of plants grown in compost 1 and 2, fertilized and unfertilized, are shown in Figure 3. Fertilized plants had a higher growth rate than unfertilized plants; the highest growth rate was that of plants grown in compost 1 .

A

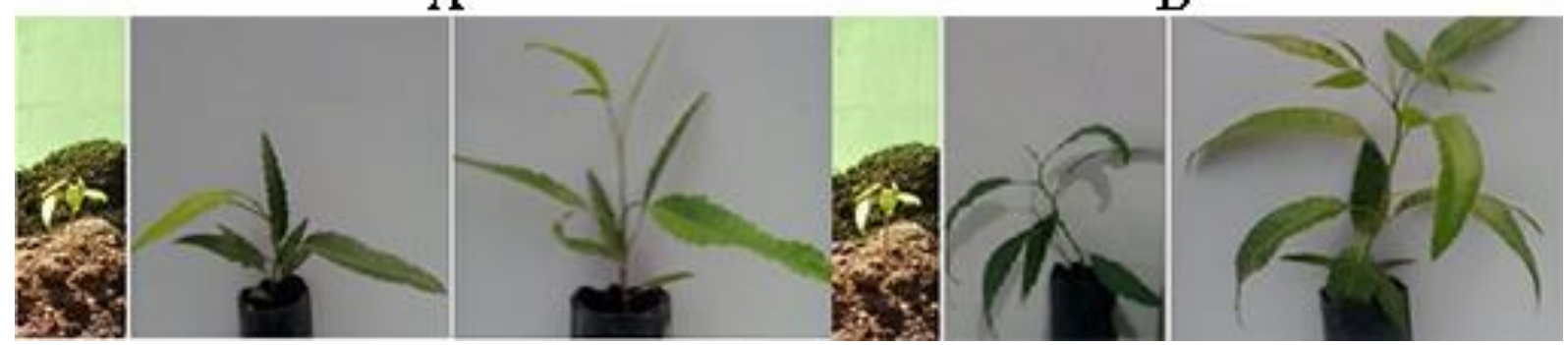

Figure 2. Development of plants grown in Acrisol at 30, 60, and 90 days of cultivation (from left to right). (A). Unfertilized soil and (B). fertilized soil.

A
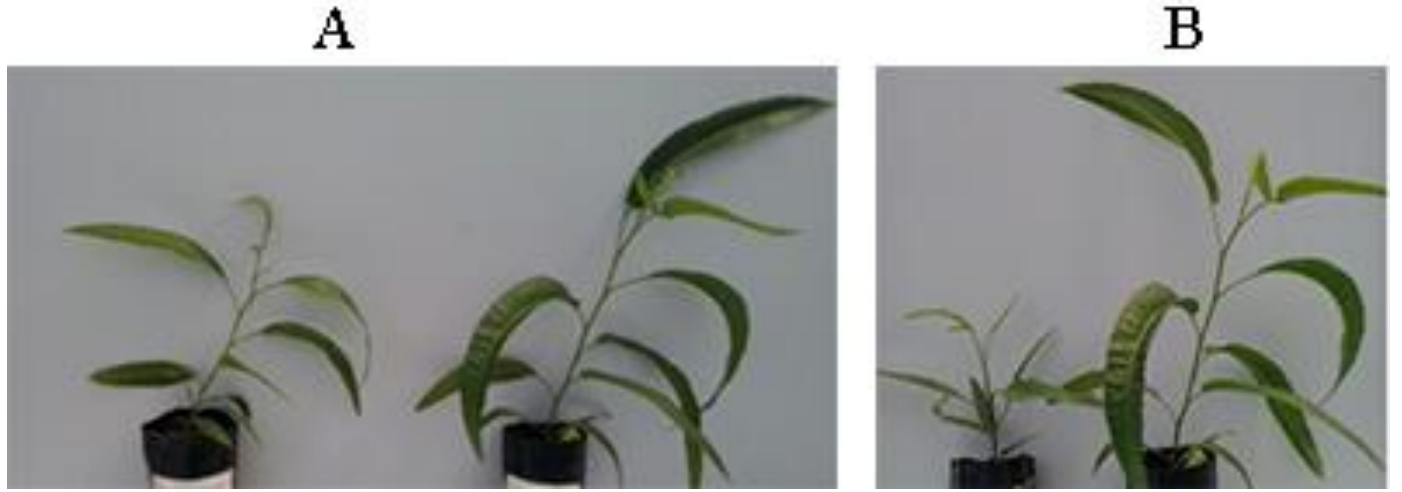

Figure 3. Development of plants grown in fertilized (right) and unfertilized (left) composts at 90 days of cultivation. (A) Plants grown in compost 1 and (B) plants grown in compost 2.

Table 3 shows the characteristics of plants cultivated in fertilized and unfertilized growing media. 
Table 3. Characteristics of aerial parts of plants grown for 90 days in fertilized and unfertilized substrates.

\begin{tabular}{|c|c|c|c|c|c|c|c|}
\hline \multirow{2}{*}{ Parameter } & \multirow{2}{*}{ Unit } & \multicolumn{2}{|c|}{ Soil } & \multicolumn{2}{|c|}{ Compost 1} & \multicolumn{2}{|c|}{ Compost 2} \\
\hline & & Unfertilized & Fertilized & Unfertilized & Fertilized & Unfertilized & Fertilized \\
\hline $\mathrm{Al}$ & $\mathrm{mg} \mathrm{g}^{-1}$ & $0.018 \pm 0.006$ & $0.030 \pm 0.011$ & $0.004 \pm 0.001$ & $<0.001$ & $0.300 \pm 0.021$ & $0.033 \pm 0.009$ \\
\hline $\mathrm{Ca}$ & $\mathrm{mg} \mathrm{g}^{-1}$ & $0.08 \pm 0.01$ & $160.5 \pm 0.0$ & $8.50 \pm 0.01$ & $85.5 \pm 0.0$ & $0.10 \pm 0.03$ & $81.0 \pm 0.1$ \\
\hline $\mathrm{Mg}$ & $\mathrm{mg} \mathrm{g}^{-1}$ & $0.36 \pm 0.02$ & $5.30 \pm 0.01$ & $0.79 \pm 0.01$ & $5.42 \pm 0.02$ & $0.50 \pm 0.05$ & $8.10 \pm 0.02$ \\
\hline $\mathrm{P}$ & $\mathrm{mg} \mathrm{g}^{-1}$ & $0.89 \pm 0.01$ & $31.1 \pm 0.0$ & $0.51 \pm 0.02$ & $102.3 \pm 0.0$ & $0.92 \pm 0.01$ & $89.0 \pm 0.0$ \\
\hline K & $\mathrm{mg} \mathrm{g}^{-1}$ & $17.02 \pm 0.01$ & $36.60 \pm 0.03$ & $30.21 \pm 0.03$ & $39.21 \pm 0.02$ & $17.30 \pm 0.01$ & $37.0 \pm 0.0$ \\
\hline $\mathrm{Na}$ & $\mathrm{mg} \mathrm{dm}-3$ & $<0.001$ & $3.00 \pm 0.02$ & $0.550 \pm 0.012$ & $7.60 \pm 0.01$ & $0.110 \pm 0.009$ & $7.10 \pm 0.02$ \\
\hline $\mathrm{N}$ & $\mathrm{mg} \mathrm{g}^{-1}$ & $12.0 \pm 0.0$ & $55.4 \pm 0.0$ & $20.1 \pm 0.1$ & $56.0 \pm 0.0$ & $11.3 \pm 0.0$ & $50.0 \pm 0.0$ \\
\hline $\mathrm{OC}$ & $\mathrm{mg} \mathrm{dm} \mathrm{m}^{-3}$ & $201.2 \pm 0.0$ & $638.4 \pm 0.0$ & $202.4 \pm 0.0$ & $640.3 \pm 0.0$ & $203.0 \pm 0.0$ & $210.0 \pm 0.0$ \\
\hline Height & $\mathrm{mm}$ & $97.1 \pm 0.0$ & $151.6 \pm 0.0$ & $80.2 \pm 0.0$ & $160.2 \pm 0.0$ & $80.1 \pm 0.0$ & $120.0 \pm 0.0$ \\
\hline Dry weight & $\mathrm{g}$ & $4.2 \pm 0.00$ & $6.2 \pm 0.0$ & $6.0 \pm 0.0$ & $10.0 \pm 0.0$ & $5.0 \pm 0.0$ & $7.0 \pm 0.0$ \\
\hline
\end{tabular}

OC, organic carbon. Values represent the mean \pm standard deviation. Three replicates.

Fertilized plants were taller and had a greater absorption of $\mathrm{C}, \mathrm{N}$, and $\mathrm{P}$ than unfertilized plants. Plants grown in compost 1 had a lower Ca content than plants grown in compost 2, probably because compost 1 had more nutrients.

The literature presents evidence of the environmental contamination potential of pharmaceuticals. Carter et al. (2014) studied the fate (in-soil degradation, transport, and plant uptake) of analytical grade carbamazepine, diclofenac, propranolol, and sulfamethazine in Tepko soil in Australia. Wu et al. (2015) studied the fate of pharmaceuticals and personal care products added to soil irrigated with treated wastewater or biosolid-amended soil. Carter et al. (2018) studied the sorption, plant uptake, and metabolism of benzodiazepines, a widely used class of pharmaceuticals that are recalcitrant to wastewater treatment. According to the authors, the mechanisms involved in pharmaceutical uptake and transport in plants are very complex. 
Few studies focus on the effects of wastewater on plant nutrient uptake. Cruz et al. (2016) reported that Tabebuia spp. grew at a faster rate in Acrisol fertilized with C, N, P, and Ca than in unfertilized soil. However, because of the complexity of plant uptake and transport mechanisms, it is very difficult to compare the effects of different wastewaters on plant nutrient absorption.

\section{CONCLUSION}

Effluent-derived fertilizer improved the characteristics of all growing media, increasing $\mathrm{pH}$ and $\mathrm{C}, \mathrm{N}, \mathrm{P}, \mathrm{K}, \mathrm{Mg}$, and Ca contents while decreasing $\mathrm{Al}$ content and soil density. However, fertilization increased $\mathrm{Na}$ content. Further research is needed to assess the effects of fertilization on soil Na levels.

Plant growth (measured by dry weight and height) and nutrient uptake were enhanced by fertilization. The best results were obtained using compost 1 , as it contained the highest concentration of nutrients.

\section{REFERENCES}

Al OMRON, A. M.; EL-MAGHRABY, S. E.; NADEEM, M. E. A.; EL-ETER, A. M.; ALMOHANI, H. Long term effect of irrigation with the treated sewage effluent on some soil properties of Al-Hassa Governorate, Saudi Arabia. Journal of the Saudi Society of Agricultural Sciences, v. 11, p. 15-18, 2012. https://doi.org/10.1016/j.jssas.2011.04.004

CARTER, L. J.; HARRIS, H.; WILLIAMS, M.; RYAN, J. J.; KOOKANA, R. S.; BOXALL, A. B. A. Fate and uptake of pharmaceuticals in soil-plant systems. Journal of Agricultural and Food Chemistry, v. 62, p. 816-825, 2014. https://doi.org/10.1021/jf404282y

CARTER, L. J.; WILLIAMS, M.; MARTIN, S.; KAMALUDEEN, S. P. B.; KOOKANA, R. S. Sorption, plant uptake and metabolism of benzodiazepines. Science of the Total $\begin{array}{llllll}\text { Environment, } & \text { v. } & 628-629, & \text { p. } & 18-25, & \end{array}$ https://doi.org/10.1016/j.scitotenv.2018.01.337

CETESB. Proposta de Índices e Qualidade de Água para o Estado de São Paulo. Coletânea de textos da Cetesb. São Paulo: CETESB, 2002.

CONAMA (Brasil). Resolução ${ }^{\circ} 357$ de 17 de março de 2005. Dispõe sobre a classificação dos corpos de água e diretrizes ambientais para o seu enquadramento, bem como estabelece as condições e padrões de lançamento de efluentes, e dá outras providências. Diário Oficial [da] União: seção 1, Brasília, DF, n. 053, p. 58-63, 18 mar. 2005.

CRUZ, A. I. G.; AMBROZIO, A. M. H.; PUGA, F. P.; SOUZA, F. L.; NASCIMENTO, M. M. Economia brasileira: conquista dos últimos dez anos e perspectivas para o futuro. Brasília: Ministério do Desenvolvimento, Indústria e Comércio Exterior, 2016. 30p.

El-HADY, B. A. A. Compare the effect of polluted and river Nile irrigation water on contents of heavy-metals of some soils and plants. Research Journal of Agriculture and Biological Sciences, v. 3, n. 4, p. 287-294, 2007.

EMBRAPA. Sistema Brasileiro de Classificação de Solos. Brasília, 2006. 306p.

EMBRAPA. Manual de Métodos de Análises Químicas para Avaliação da Fertilidade do Solo. Brasília, 2009. 627p. 
EMBRAPA. Manual de Métodos de Análises de Solo. Brasília, 2011. 225 p.

EMBRAPA. Manual de viveiro e produção de mudas: espécies arbóreas nativas do Cerrado. Brasília, 2016. 124p.

FAO. The Importance of Soil Organic Matter: key to drought-resistant soil and sustained food production. Rome, 2005. 95p.

FAO. Advances in the Assessment and Monitoring of Salinization and Status of Biosaline Agriculture. Reports of Expert Consultation Held in Dubai, United Arab Emirates. Rome, 2007.

GUIMARÃES, D. V.; GONZAGA, M. I. S.; MELO NETO, J. O. Management of soil organic matter and carbon storage in tropical fruit crops. Revista Brasileira de Engenharia Agrícola e Ambiental, v. 18, n. 3, p. 301-306, 2014. https://dx.doi.org/10.1590/S141543662014000300009

GOMES, K. C. O.; PAIVA, H. N.; NEVES, J. C. L.; BARRIS, N. F.; SILVA, S. R. Influência da saturação por bases e do fosfato no crescimento de mudas de Angico-Branco. Revista Árvore, v. 28, n. 5, p. 785-792, 2004.

GOUVEIA, N. Resíduos sólidos urbanos: Impactos socioambientais e perspectiva de manejo sustentável com inclusão social. Ciência e Saúde coletiva, v. 17, n. 6, p. 1503-1510, 2012.

KALYVA, M. Fate of pharmaceuticals in the environment: A review. Sweden: Umeå University, Dept. of Ecology and Environmental Science, 2017. 30 p.

KAUR, V.; SHARMA, G. Effects of industrial effluent on soil characteristics: A review. International Journal of Advances in Engineering Science and Technology, v. 3, n. 3, p. 201-207, 2013.

KARLEN, D. L.; RICE, C. W. Enhancing Soil Health to Mitigate Soil Degradation. Switzerland: MDPI, 2017. 338p.

LAL, R. Soils and sustainable agriculture: A review. Agronomy for Sustainable Development, v. 28, n. 1, p. 57-64, 2008. https://doi.org/10.1051/agro:2007025

MAFIA, R. G.; ALFENAS, A. C.; ANDRADE, G. G. G.; NEVES, D. A.; GRAÇA, R. N.; ALONSO, S. K. Incidência de Meliola rhoina como fator limitante à produção de mudas de Schinus molle para fins de arborização. Fitopatologia Brasileira, v. 29, n. 2, p. 224 , 2004.

MELO, S. A. S.; TROVO, A. G.; BAUTITZ, I. R.; NOUGUEIRA, R. F. P. Degradação de fármacos residuais por processos oxidativos avançados. Química Nova, v. 32, n. 1, p. 188-197, 2009.

MISIEWICZ, T.; SHADE, J.; CROWDER, D.; DELATE, K.; SCILIGO, A.; SILVA, E. Increasing Agricultural Sustainability Through Organic Farming: Outcomes from the 2016 Organic Confluences Summit. Washington: The Organic Center, 2017. 32 p.

OSAIGBOVO, A. U.; ORHUE, E. R. Influence of pharmaceutical effluent on some soil chemical properties and early growth of maize (Zea mays L.). African Journal of Biotechnology, v. 5, n. 12, p. 1612-1617, 2006. 
RUSAN, M. J. M.; HINNAWI, S.; ROUSAN, L. Long term effect of waste water irrigation of forage crops on soil and plant quality parameters. Desalinization, v. 215, n. 1-3, p. 143152, 2007. https://doi.org/10.1016/j.desal.2006.10.032

SRINIVASAN, V.; MAHESWARAPPA, H. P.; LAL, R. Long term effects of topsoil depth and amendments on particulate and non particulate carbon fractions in a Miamian soil of Central Ohio. Soil \& Tillage Research, v. 121, p. 10-17, 2012. https://doi.org/10.1016/j.still.2012.01.014

SUMNER, M. E. Sodic soils: New perspectives. Australian Journal of Soil Research, v. 31, n. 6, p. 683-750, 1993. https://doi.org/10.1071/SR9930683

VAN RAIJ, B. et al. (Eds.). Recomendações de Adubação e Calagem para o Estado de São Paulo. 2. ed. Campinas: IAC, 1997. 285 p. (Boletim técnico, 100).

WU, X.; DODGEN, L. K.; CONKLE, J. L.; GAN, J. Plant uptake of pharmaceutical and personal care products from recycled water and biosolids: A review. Science of the Total Environment, v. 536, p. 655-666, 2015. https://doi.org/10.1016/j.scitotenv.2015.07.129

YADAV, R.; GOYAL, B.; SHARMA, R. K.; S. DUBEY, S. K.; MINHAS, P. S. Post-irrigation impact of domestic sewage effluent on composition of soils, crops and groundwater: A case study. Environment International, v. 28, n. 6, p. 481-486, 2002. https://doi.org/10.1016/S0160-4120(02)00070-3 